\title{
$\beta$-adrenoceptor blocker treatment and the cardiac $\beta$-adrenoceptor-G-protein(s)-adenylyl cyclase system in chronic heart failure
}

\author{
Otto-Erich Brodde
}

Received: 18 September 2006 / Accepted: 17 November 2006 / Published online: 11 January 2007

(C) Springer-Verlag 2007

\begin{abstract}
Recent studies showed that chronic $\beta$-adrenoceptor (AR) blocker treatment exerts beneficial effects in patients with chronic heart failure (CHF). In CHF, sympathetic drive to the heart is increased, and this causes pathological changes in cardiac $\beta-A R-G-p r o t e i n(s)-$ adenylyl cyclase system: Cardiac $\beta-1$ AR are decreased, and amount and activity of cardiac $\mathrm{G}_{\mathrm{i}}$-protein and $\mathrm{G}$ protein-coupled receptor kinase (GRK) are increased resulting in diminished cardiac $\beta$-AR functional responsiveness. One possible mechanism of beneficial effects of $\beta$-AR blockers could be that they prevent adverse effects of increased sympathetic activity and up-regulate cardiac (and vascular) $\beta$-AR density, and by this, enhance $\beta$-ARmediated effects. Another possibility could be that chronic $\beta$-AR blocker treatment normalizes activity of $\mathrm{G}_{\mathrm{i}}$-protein and may thereby restore $\beta$-AR functional responsiveness. Moreover, failing human heart exhibits an inverse forcefrequency relationship. $\beta$-AR blockers reduce heart rate; this may, therefore, improve force of contraction. One of the strongest stimuli to activate GRK is increased sympathetic activity (as in $\mathrm{CHF}$ ) via $\beta$-AR stimulation. $\beta$-AR blockers, by blocking $\beta$-AR, can prevent GRK activation and/or can reduce the (previously enhanced) GRK activity, and this might - at least partly — contribute to beneficial effects of $\beta$-AR blockers in CHF treatment. Finally, the "loss-of-function" Arg389Gly $\beta-1$ AR polymorphism seems to determine heart rate and blood pressure responses
\end{abstract}

Dedicated to Professor Dr. Karl-Heinz Jakobs at the occasion of his 65 th birthday.

\section{O.-E. Brodde $(\bowtie)$}

Department of Nephrology and Pathophysiology,

University of Essen School of Medicine,

IG I., 9.OG, Hufelandstr. 55,

45147 Essen, Germany

e-mail: otto-erich.brodde@uk-essen.de to $\beta-1$ AR blocker administration: Arg389Arg $\beta-1$ AR subjects exhibit stronger effects than subjects with one or two Gly389 alleles. Thus, it might be predicted that patients homozygous Arg389 $\beta-1$ AR should be good responders, whereas patients homozygous Gly389 $\beta-1$ AR polymorphism should be poor or non-responders.

Keywords $\beta_{1}$-adrenoceptors $\cdot \beta_{2}$-adrenoceptors Chronic heart failure $\cdot \beta$-adrenoceptor blocker treatment

\section{Introduction}

The endogenous catecholamines noradrenaline and adrenaline, the transmitter of the sympathetic nervous system, evoke their biological effects through stimulation of specific membrane-bound receptors, the "adrenoceptors". The subclassification of adrenoceptors (AR) into the subtypes $\alpha$ and $\beta$ was initially introduced into the pharmacology of the sympathetic nervous system in 1948 by Ahlquist (1948) to explain the differences in action of noradrenaline and adrenaline. With the development of new and more specific drugs, it rapidly became apparent that both $\alpha$ - and $\beta$-AR can be subdivided into at least two subtypes: $\alpha$-AR in the subtypes $\alpha-1$ and $\alpha-2$ (Langer 1974; Starke 1977), $\beta$-AR into the subtypes $\beta-1$ and $\beta-2$ (Lands et al. 1967). In the last 10 years, with the introduction of molecular biology techniques into pharmacology, further AR subtypes have been introduced. At present, for each $\alpha$ $1, \alpha-2$ and $\beta$-AR, three subtypes have been identified pharmacologically and through molecular cloning: $\alpha-1 \mathrm{~A}$, $\alpha-1 \mathrm{~B}$ and $\alpha-1 \mathrm{D} ; \alpha-2 \mathrm{~A}, \alpha 2-\mathrm{B}$ and $\alpha-2 \mathrm{C} ; \beta-1, \beta-2$ and $\beta-3$ AR (Bylund et al. 1994).

The most important $\alpha$-AR-mediated physiological effects of catecholamines are vasoconstriction (via postsynaptic $\alpha-1$ 
and $\alpha-2$ AR stimulation) and feedback regulation of sympathetic nerve stimulation-induced release of catecholamines from sympathetic nerve endings (via presynaptic $\alpha-2$ AR stimulation). The most important $\beta-1$ AR-mediated effects of catecholamines are their effects on the heart, lipolysis and regulation of renin release (and by this activation of the renin-angiotensin-aldosteron system); the most important $\beta-2$ AR-mediated effects of the catecholamines are bronchodilation, relaxation of uterine and vascular smooth muscles and glycogenolysis. The endogenous catecholamines noradrenaline and adrenaline are equipotent at $\beta-1$ AR (i.e. the same concentration of catecholamine evokes nearly the same effect), whereas at $\beta-2$ AR adrenaline is $10-30$ times more potent than noradrenaline. In addition, it should be emphasized that the organ-specific subclassification of $\beta$-AR into cardiac $\beta-1$ and vascular and bronchial smooth muscle $\beta-2$ AR is an oversimplification: It soon became apparent, and is now generally accepted, that in a variety of tissues, $\beta-1$ and $\beta-2$ AR coexist, whereby normally one subtype predominates. This holds true also for the human heart where $\beta-1$ and $\beta-2$ AR coexist; both subtypes can mediate positive inotropic and chronotropic effects, but the effects via cardiac $\beta-1$ AR stimulation predominate under physiological conditions (Brodde and Michel 1999).

$\beta$-AR blockers ( $\beta$-AR antagonists) are compounds that bind to $\beta$-AR but - in contrast to $\beta$-AR agonists - do not evoke physiological effects but inhibit the effects of $\beta$-AR agonists (endogenously released or exogenously applied) by competing with the agonist for the binding site at the $\beta$ AR. Thus, in the presence of a $\beta$-AR blocker, the doseresponse curve for the agonist is shifted to the right so that any tissue response requires a higher agonist concentration. The effects of $\beta$-AR blockers can be overcome by increasing the concentration of the agonist-a characteristic of a "competitive antagonism".

As mentioned above, $\beta$-AR are involved in manifold effects of the sympathetic nervous system; in addition, an increased activity of the sympathetic nervous system plays an important role in various cardiovascular diseases (hypertension, coronary artery disease, ventricular and supraventricular arrhythmias, chronic heart failure $[\mathrm{CHF}]$ ). Thus, it is quite understandable that $\beta$-AR blockers play an important therapeutic role in treatment of these diseases.

Principally, $\beta$-AR blockers can be classified into three classes/generations (Bristow 2000); some examples for each class/generation are given in Table 1.

"First class/generation" $\beta$-AR blockers are drugs that have the same affinities at $\beta-1$ and $\beta-2$ AR - "nonselective $\beta$-AR blockers". Propranolol was the first $\beta$-AR blocker introduced for the treatment of angina (Black et al. 1964). Propranolol is a nonselective $\beta-1$ and $\beta-2$ AR antagonist, and because the vast majority of development work in various clinical indications was performed with propranolol, it is the drug with the most accumulated clinical experience. Examples for other nonselective $\beta$-AR blockers are nadolol or timolol.

"Second class/generation" $\beta$-AR blockers are drugs that have a higher affinity at $\beta-1$ than at $\beta-2$ AR-however, it should be emphasized that this $\beta-1$ AR selectivity is always relative and is lost with higher doses (as discussed above, in many human tissues, the heart included, $\beta-1$ and $\beta-2$ AR coexist - thus, the term "cardioselective $\beta$-AR blocker" is not correct; the appropriate term would be $\beta-1$ AR selective blocker). Nevertheless, the $\beta-1$ AR selectivity is, for the most clinical indications of $\beta$-AR blockers, a beneficial property because in therapeutic (low) doses, effects via $\beta-2$ AR stimulation (vasodilation, bronchodilation, glycogenolysis) should not be affected. Therefore, during treatment with a $\beta-1$ AR selective blocker, less vasoconstriction, bronchoconstriction and (in patients with diabetes mellitus) hypoglycemias should occur.

However, generally, the use of $\beta-1$ AR selective blockers should be avoided in patients with asthma bronchiale, although it has been shown that patients with chronic obstructive pulmonary diseases and cardiovascular diseases benefit from $\beta-1$ AR selective blocker treatment very similar as patients with cardiovascular diseases without

Table 1 Classification of $\beta$-AR blockers

\begin{tabular}{ll}
\hline Classification & $\beta$-AR blockers \\
\hline First generation & $\beta-1$ and $\beta-2$ AR nonselective, no additional vasodilating activity (propranolol, nadolol, timolol) \\
Second generation & $\beta-1$ (or $\beta-2^{\text {a }}$ ) AR selective, no additional vasodilating activity (atenolol, bisoprolol, metoprolol) \\
Third generation & $\beta-1$ and $\beta-2$ AR nonselective or $\beta-1$ AR selective with additional vasodilating activity \\
& Carvedilol nonselective, vasodilation via $\alpha-1$ AR blockade \\
& Bucindolol nonselective, vasodilation via $\alpha-1$ AR blockade \\
& Celiprolol $\beta-1$ AR selective, vasodilation via $\beta-2$ AR agonism \\
& Nebivolol $\beta-1$ AR selective, vasodilation via the L-arginine/NO-system
\end{tabular}

It should be mentioned that some $\beta$-AR blockers (for example pindolol, acebutolol, oxprenolol) do not only evoke antagonistic effects at the $\beta$ AR but they also possess a certain degree of partial agonistic activity, $\beta$-AR blockers with ISA. However, for most of the clinical indications of the $\beta$-AR blockers, the ISA is not desirable.

${ }^{a} \beta-2$ AR selective: ICI 118,551 but not in use for humans 
airway disease (Gottlieb et al. 1998). In addition, bronchoconstriction occurring during treatment with $\beta-1$ AR selective blockers can be better overcome with $\beta-2$ AR mimetics than bronchoconstriction induced by treatment with a nonselective $\beta$-AR blocker.

"Third class/generation" $\beta$-AR blockers are drugs with additional vasodilating properties (Table 1). The vasodilating effects of carvedilol and bucindolol are likely due to their $\alpha-1$ AR blocking activity, that of celiprolol is brought about by its $\beta-2$ AR agonistic activity, and that of nebivolol appears to be due to its NO-releasing effect from the endothelium.

\section{Effects of chronic $\beta$-adrenoceptor blocker treatment on the cardiac $\beta$-adrenoceptor-G-protein(s)-adenylyl cyclase system in chronic heart failure}

It is now generally accepted that chronic $\beta$-AR blocker treatment exerts beneficial effects in patients with coronary artery disease and hypertension; recent studies have shown that they are also quite effective in treatment of $\mathrm{CHF}$ patients (Bristow 2000).

In the following, a possible role of changes in the cardiac $\beta$-AR-G-protein(s)-adenylyl cyclase system as one reason for the beneficial effects of chronic $\beta$-AR blocker treatment in CHF is discussed.

In heart failure, sympathetic activity is increased. Thus, numerous studies have shown that plasma noradrenaline levels are elevated in CHF patients (Cohn 1990). The increase in plasma noradrenaline levels, that has been taken as a guide to prognosis for these patients (Cohn et al. 1984), is caused by an enhanced cardiac noradrenaline spillover due to the increased sympathetic drive to the heart (for review, see Esler et al. 1997) and a decreased activity and density of the neuronal noradrenaline re-uptake transporter (uptake $_{1}$; Böhm et al. 1995; Eisenhofer et al. 1996). Accordingly, myocardial catecholamine stores are depleted in CHF patients (Chidsey and Braunwald 1966). Thus, in $\mathrm{CHF}$, cardiac $\beta$-AR are chronically activated by the increased sympathetic activity (i.e. increased catecholamine concentrations). This leads to a decrease in cardiac $\beta-A R$, the most powerful physiologic mechanism to acutely augment contractility (and heart rate) in the human heart (Brodde et al. 1995).

Since the original findings of Bristow et al. (1982), that in the severely failing human heart, $\beta-A R$ are decreased, numerous studies on alterations of the $\beta$-AR system in the failing human heart have been performed. It is now generally accepted that, in the failing human heart, $\beta-1$ AR are decreased, $\beta-2$ AR may or may not be decreased but are uncoupled from the effector system adenylyl cyclase, the amount and activity of $\mathrm{G}_{\mathrm{s}}$-protein is un- changed, the amount and activity of $\mathrm{G}_{\mathrm{i}}$-protein is increased as is the amount and activity of the G-protein-coupled receptor kinase $(\mathrm{GRK})$; on the other hand, activities of adenylyl cyclase and protein kinase A are unchanged (for reviews, see Brodde and Michel 1999; Port and Bristow 2001; Lohse et al. 2003). The consequence of these changes is a reduction in cardiac $\beta$-AR functional responsiveness. However, in heart failure, not only functional responsiveness of $\beta-1$ and $\beta-2$ AR but also that of all receptors coupled to the $\mathrm{G}_{\mathrm{s}}$-protein (histamine $\mathrm{H}_{2}$ receptors, serotonin $5-\mathrm{HT}_{4}$ receptors) are diminished (for references, see Brodde and Leineweber 2004) presumably by the increase in the inhibitory G-protein $\mathrm{G}_{\mathrm{i}}$ that might impair cyclic adenosine monophosphate (AMP) formation. In fact, it has recently been shown that increases in $\mathrm{G}_{\mathrm{i}}$-protein can suppress receptor-mediated activation of adenylyl cyclase (for references, see El-Armouche et al. 2003). Taken together, in the failing human heart, responses to all receptors that involve increases in the intracellular level of cyclic AMP appear to be diminished.

It should be mentioned, however, that recently, Brattelid et al. (2004) observed that, in failing human ventricular myocardium, phosphodiesterase inhibition (by 3-isobutyl1-methyl-xanthine [IBMX]) uncovers functional $5-\mathrm{HT}_{4}$ receptors mediating increases in force of contraction, whereas non-failing human ventricular myocardium appears to lack those functional $5-\mathrm{HT}_{4}$ receptors (for references, see Brodde et al. 1995).

\section{Effects on $\beta$-adrenoceptor density}

One possible mechanism of beneficial effects of $\beta$-AR blockers could be that they can up-regulate cardiac (and vascular) $\beta$-AR density, and by this, can enhance $\beta$-ARmediated effects. This has been initially shown in the rat where chronically administered propranolol increased $\beta$ AR density in heart, lung and circulating lymphocytes (Aarons and Molinoff 1982). Studies in humans, by using circulating lymphocytes containing a homogeneous population of $\beta-2 \mathrm{AR}$, have confirmed these findings: Chronic treatment of healthy volunteers with propranolol significantly increased lymphocyte $\beta-2$ AR (for references, see Brodde and Wang 1988). After withdrawal of propranolol, $\beta-2$ AR density declined slowly and was still increased for further 3-4 days, although no propranolol was detectable in plasma after $24 \mathrm{~h}$ (Fig. 1). Thus, for 3-4 days, there is an increased $\beta$-AR density not protected by the $\beta$-AR blocker; this could well be the reason for the often observed $\beta$-AR supersensitivity after abrupt propranolol withdrawal.

Subsequently, also in human heart and vascular tissue, $\beta$-AR up-regulation by chronic $\beta$-AR blocker treatment could be demonstrated. In atrial tissue from patients 
Fig. 1 Effects of propranolol $(4 \times 40 \mathrm{mg} /$ day $)$ on lymphocyte $\beta_{2}$-AR density in six male volunteers. Ordinate, left lymphocyte $\beta_{2}$-AR density in ICYP binding sites/cell; right plasma propranolol levels in $\mathrm{ng} / \mathrm{ml}$. Solid horizontal line and broken lines mean \pm SEM of lymphocyte pre-drug $\beta_{2}$-AR density. $A b$ scissa days of study. ${ }^{*} P<0.05$ vs pre-drug levels. Modified from Brodde et al. (1985)

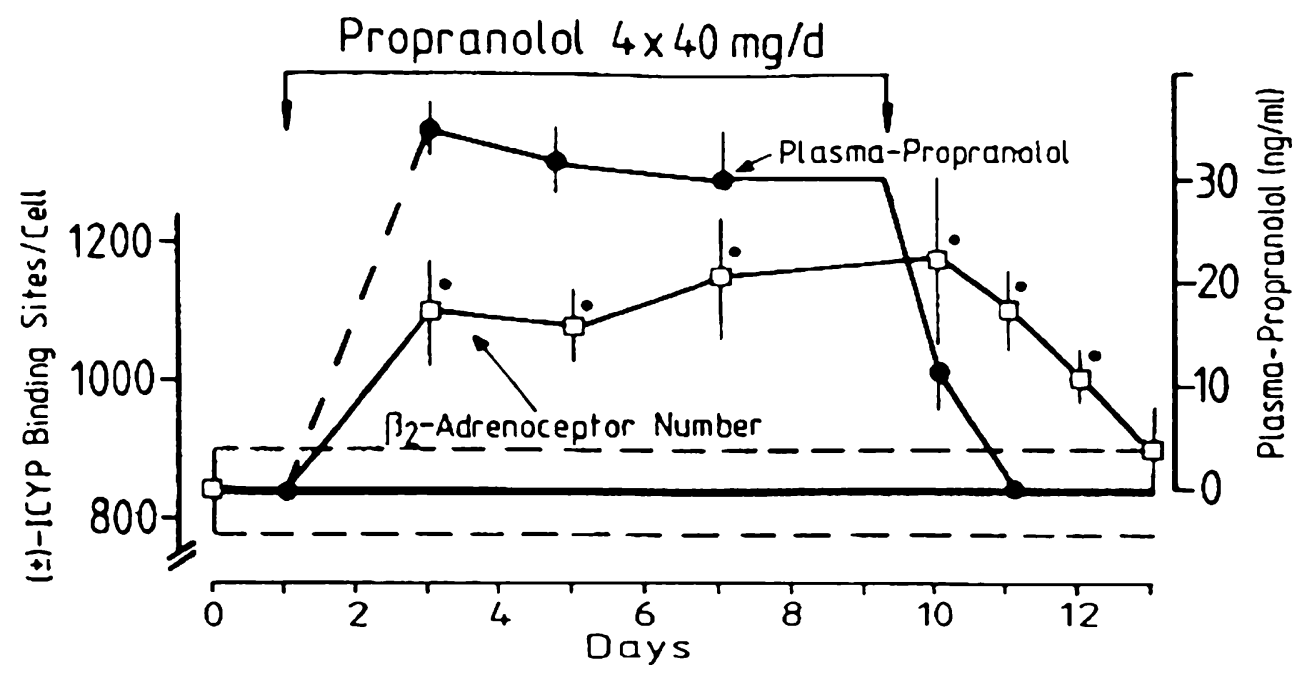

undergoing coronary artery bypass grafting (CABG) and chronically treated with the nonselective $\beta$-AR blocker propranolol and sotalol and with the $\beta-1$ AR selective blockers metoprolol, atenolol and bisoprolol, $\beta$-AR density was significantly higher than in patients not treated with $\beta$ AR blockers. Moreover, it was also found that $\beta-A R$ blockers up-regulate $\beta$-AR density obviously in a $\beta$-AR subtype-selective manner. Only in patients treated with the $\beta-1$ and $\beta-2$ AR nonselective blocker propranolol right atrial $\beta-1$ and $\beta-2$ AR density was increased, whereas in patients treated with the $\beta-1$ AR selective blockers, only right atrial $\beta-1$ AR but not $\beta-2$ AR density was increased. Similar findings were also obtained for human saphenous vein and lymphocyte $\beta-2$ AR: only propranolol increased $\beta$-2 AR density, whereas atenolol, metoprolol or bisoprolol did not (Fig. 2; for references, see Brodde et al. 1990).

As discussed above, a general feature of CHF patients is a reduced cardiac $\beta$-AR density (for reviews, see Brodde and Michel 1999; Lohse et al. 2003; Brodde and Leineweber 2004). Because the human heart contains only a few spare $\beta$-AR (for references, see Brodde 1993), any decrease in number of available surface receptors must automatically lead to a decreased functional response. Thus, a $\beta-A R$ blocker-evoked up-regulation would be helpful in restoring maximal contractile responses to $\beta$-AR stimulation. In fact, some $\beta-1$ AR blockers such as metoprolol or bisoprolol have been shown to up-regulate $\beta$-AR in the heart of patients with CHF (Gilbert et al. 1996; Heilbrunn et al. 1989; Sigmund et al. 1996; Waagstein et al. 1989). Interestingly, several studies in patients with coronary artery disease have shown that chronic treatment with $\beta-1$ AR selective blockers such as metoprolol, atenolol or bisoprolol sensitizes cardiac $\beta$-2 AR function in vitro (Hall et al. 1990; Motomura et al. 1990) and in vivo (Hall et al. 1991). Whether this occurs also in CHF patients and whether this may contribute to the beneficial effects of $\beta$ 1 AR blockers in these patients is still a matter of debate. It is also not known which mechanism underlies this "crosstalk" between human cardiac $\beta-1$ and $\beta-2$ AR.

It is, however, very interesting to note that such a $\beta$-AR up-regulation has, up to now, only been found for "first and second generation" $\beta$-AR blockers, whereas the "third generation" $\beta$-AR blocker carvedilol did not up-regulate cardiac $\beta-A R$ in $\mathrm{CHF}$ patients, although it was as effective as metoprolol in improving cardiac performance in these patients (Gilbert et al. 1996). Similarly, also the "third generation" $\beta$-AR blocker bucindolol did not up-regulate cardiac $\beta$-AR in CHF patients (Bristow 2000).

On the other hand, no data are known on the effects of nebivolol, another "third generation" $\beta$-AR blocker (see Table 1), on cardiac $\beta$-AR. Thus, it is not known at present whether or not the lack of effect on cardiac $\beta$-AR density of carvedilol and bucindolol is a "third generation" $\beta$-AR blocker "class effect". However, alternative explanations do exist: It has been recently shown that carvedilol binds very firmly to $\beta-A R$, and it is extremely difficult to remove carvedilol, once bound to the $\beta-\mathrm{AR}$, from the binding site (Kindermann et al. 2004). Thus, it is well possible that such firmly bound carvedilol may mask increases in $\beta$-AR. On the other hand, for bucindolol, several authors have found that it exerts partial intrinsic sympathomimetic activity (ISA) in the human myocardium (Maack et al. 2000, 2003; Andreka et al. 2002). Previous studies had shown, however, that $\beta$-AR blockers with intrinsic sympathomimetic activity decrease cardiac $\beta$-AR density (Michel et al. 1988), and this would explain the lack of cardiac $\beta$-AR up-regulation during chronic bucindolol treatment.

\section{Effects on $\mathbf{G}_{\mathbf{i}}$-proteins}

Chronic activation of cardiac $\beta$-AR by $\beta$-AR agonists (either exogenously administered or endogenously released) is accompanied by increases in the amount and/or activity 


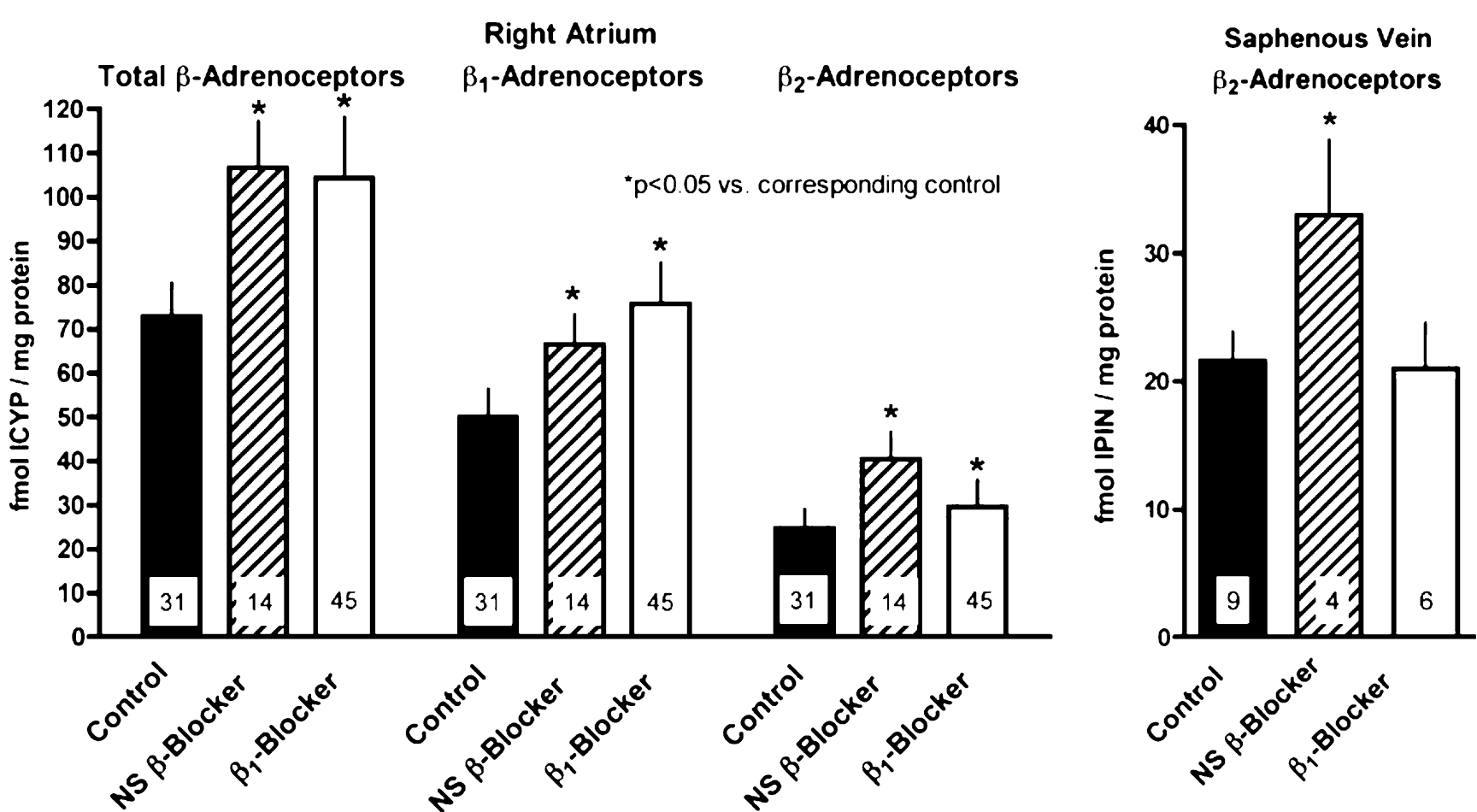

Fig. 2 Effect of chronic $\beta$-AR blocker treatment on right atrial and saphenous vein $\beta$-AR in patients undergoing coronary artery bypass surgery. Ordinates (from left to right) right atrial total $\beta$-AR density, $\beta_{1}$-AR density and $\beta_{2}$-AR density in fmol ICYP specifically bound/ $\mathrm{mg}$ protein; saphenous vein $\beta_{2}$-AR density in fmol $\left[{ }^{125} \mathrm{I}\right]$ iodopindolol (IPIN) specifically bound/mg protein. Numbers at the bottom of the

column number of patients studied. NS $\beta$-Blocker patients treated with nonselective $\beta$-AR blocker propranolol and sotalol; $\beta_{1}$-Blocker patients treated with the $\beta_{1}$-AR selective blocker metoprolol, atenolol and bisoprolol. Modified from Michel et al. (1988) and Brodde et al. (1989)

of the inhibitory G-protein $\mathrm{G}_{\mathrm{i}}$ (for review, El-Armouche et al. 2003). Thus, $\beta$-AR blocker, by inhibiting $\beta$-AR activation, could prevent $\mathrm{G}_{\mathrm{i}}$-activation or reduce an already enhanced $\mathrm{G}_{\mathrm{i}}$-activity. Indeed, in patients with congestive heart failure, it has been shown that chronic treatment with metoprolol led to a significant reduction in the amount of $\mathrm{G}_{\mathrm{i}}$ (Sigmund et al. 1996).

In this context, it should be mentioned that the role of increases in cardiac $\mathrm{G}_{\mathrm{i}}$-protein in CHF is still a matter of debate. On the one side, it could cause impairment of cyclic AMP formation and by this attenuation of positive inotropic effects evoked by stimulation of $\beta-1$ and $\beta-2$ AR (and of all other $\mathrm{G}_{\mathrm{s}}$-protein-coupled receptors, see above). This might be detrimental to the heart because the $\beta$-AR-G-protein(s)adenylyl cyclase system is the most powerful physiologic mechanism in the human heart to acutely increase myocardial performance (Brodde et al. 1995). On the other hand, it could be protective to the heart because it could augment antiapoptotic effects. Recent studies had shown that, at least in rat cardiomyocytes, cardiac $\beta$-AR stimulation does not only evoke chrono- and inotropic effects but can also affect apoptosis with $\beta-1$ AR (via the $G_{s}$-protein) inducing proapoptotic effects and $\beta-2$ AR (via the $G_{i}$-protein) inducing antiapoptotic effects (Communal et al. 1999; Xiao et al. 2004). If this would occur also in the human heart, the increase in $\mathrm{G}_{\mathrm{i}}$-protein in CHF should promote antiapoptosis.

Moreover, studies in rats had shown that $\mathrm{G}_{\mathrm{i}}$-protein appears to be involved in catecholamine-induced arrhythmias. Thus, inactivation of $\mathrm{G}_{\mathrm{i}}$-protein by pertussis toxin treatment in rats led to a marked increase in the arrhythmogenic effects of isoprenaline (Grimm et al. 1998). On the other hand, chronic treatment of rats with isoprenaline caused decreases in $\beta$-AR and increases in $\mathrm{G}_{\mathrm{i}}$-protein, and this was accompanied by a marked decrease in isoprenaline- or forskolin-induced arrhythmias (Eschenhagen et al. 1996). Taken together, these data are in favour of the idea that the increase in cardiac $\mathrm{G}_{\mathrm{i}}$-protein might protect the heart against catecholamine-induced arrhythmias.

\section{Effects on force-frequency relationship}

One of the most striking effects of a $\beta$-AR blocker treatment is a decrease in heart rate; this is the desired effect in treatment of patients with coronary artery disease. However, such a heart rate-decreasing effect of $\beta$-AR blockers could also contribute to their beneficial effects in CHF patients. In normal human subjects, increases in heart rate lead to enhanced left ventricular force of contraction (positive force-frequency relationship, "Bowditch-Treppe phenomenon"; Bowditch 1871) and this positive force-frequency effect is enhanced by $\beta$-AR stimulation (Bhargava et al. 
1998). CHF patients show marked reduction in the positive force-frequency relationship (for references, see Just 1996) and no augmentation by $\beta$-AR stimulation (Bhargava et al. 1998). $\beta$-AR blockers decrease heart rate; this might shift the force-frequency relationship towards lower rates of beating and, by this, may improve force of contraction in CHF patients.

It should be, however, mentioned that the heart ratelowering effects of the $\beta$-AR blockers occur very fast, whereas the clinical effects in CHF (improvement of left ventricular ejection fraction [LVED]) develop very slowly.

\section{Effects on G-protein-coupled receptor kinase activity}

G-protein-coupled receptor kinases (GRK) are a family of serine/threonine kinases that phosphorylate only agonistoccupied receptors, thereby facilitating binding of arrestins to the phosphorylated receptor. This leads to an uncoupling of the receptor from the $\mathrm{G}_{\mathrm{s}}$-adenylyl cyclase system and, finally, to a decrease in $\beta$-AR responses to agonist stimulation. In the heart, three GRK isoforms are expressed: GRK2 (or $\beta A R K 1)$, GRK3 and GRK5, whereby GRK2 is the most abundant isoform (Penn et al. 2000). Several studies have demonstrated that one of the strongest stimuli to activate GRK2 is increased sympathetic activity via $\beta$-AR stimulation, whereas $\alpha-1$ AR stimulation appears not to activate GRK2 (Iaccarino et al. 1998; Penela et al. 2003, 2006). As discussed above, in CHF, sympathetic activity is increased; accordingly, it could be expected that activity of GRK2 is increased. This has in fact been shown for cardiac GRK in patients with end-stage heart failure (Ungerer et al. 1993; Leineweber et al. 2003, 2005). Studies, mainly in transgenic mice, have shown that such an increase in the activity of
GRK2 is obviously associated with a decrease in contractile force, and this can be restored by inhibition of GRK2 (Hata et al. 2004). Because $\beta$-AR stimulation is strongly linked to GRK2 activation, it could be expected that $\beta$-AR blockers should prevent GRK increases and/or should decrease an already increased GRK2 activity. In fact, in vivo studies in pigs have shown that treatment with the $\beta-1$ AR blocker bisoprolol causes down-regulation of GRK2 (Ping et al. 1995); similarly, in mice, treatment with the $\beta$-AR blockers atenolol or carvedilol decreased GRK2 activity (Iaccarino et al. 1998). We have recently shown that this appears to be true also for human cardiac GRK2: In patients with different degrees of CHF treated with the $\beta-1$ AR blockers metoprolol or bisoprolol, right atrial GRK2 activity was, in each New York Heart Association (NYHA) class, lower than in patients not treated with $\beta$-AR blockers (Fig. 3). Thus, it could be that the ability of $\beta$-AR blockers to prevent activation of GRK2 or to reduce the (in CHF enhanced) activity of GRK2 might - at least partly - contribute to the beneficial effects of $\beta$-AR blockers in treatment of CHF.

\section{Possible role of $\beta-1$ adrenoceptor polymorphisms}

Recent studies have shown that $\beta-1$ AR are polymorphic; there are at least two functionally important single nucleotide polymorphisms (SNPs) in the $\beta-1$ AR gene: at position 49 in the extracellular amino-terminus of the $\beta-1$ AR, Ser is substituted by Gly (Ser49Gly), and at position 389 in the intracellular carboxy-terminus, Arg is substituted by Gly (Arg389Gly). The Ser49Gly polymorphism of the $\beta-1$ AR affects the extent in agonist-induced downregulation with Gly49 undergoing much more rapid down-regulation than Ser49. The Arg389Gly $\beta-1$ AR is a

Fig. 3 Effect of long-term $\beta$ AR blocker treatment (with metoprolol or bisoprolol) on right atrial GRK activity in patients with different degrees of heart failure. Ordinate GRK activity in cpm $\left[{ }^{32} \mathrm{P}\right]$ rhodopsin/ $\mathrm{mg}$ protein. Numbers at the bottom of the column number of patients studied. Modified from Leineweber et al. (2005)

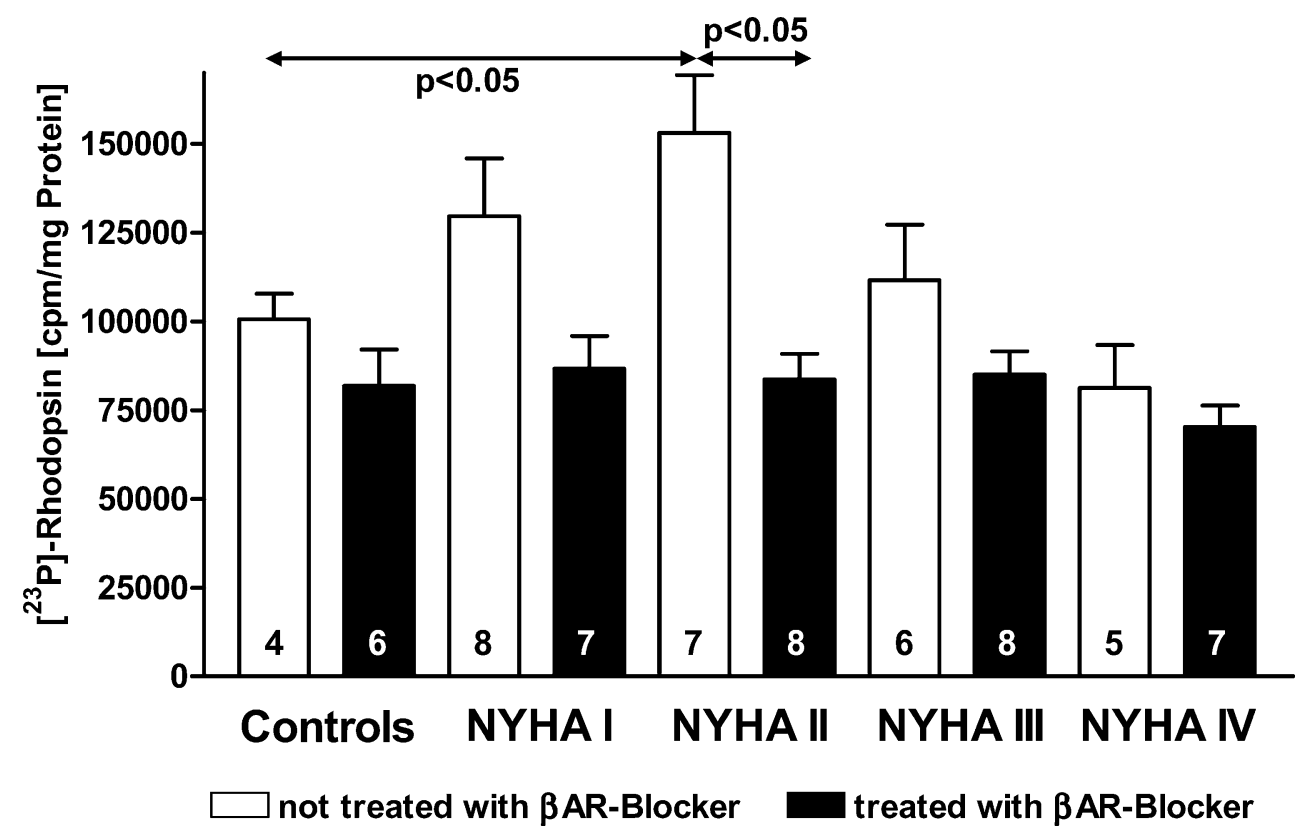


"loss-of-function" polymorphism with the Arg389 $\beta-1$ AR exhibiting a three- to fourfold higher isoprenaline-stimulated adenylyl cyclase activity than the Gly389 $\beta-1$ AR variant due to a better coupling of the Arg389 to $G_{s}$-protein than the Gly389 $\beta-1$ AR variant (for recent reviews, see Small et al. 2003; Leineweber et al. 2004; Kirstein and Insel 2004; Brodde et al. 2006).

Between codon 49 and 389 SNPs of the $\beta-1$ AR, a strong linkage disequilibrium exists. Thus, subjects homozygous for the Gly49 variant are nearly always homozygous for the Arg389 variant, and vice versa; subjects homozygous for the Gly389 variant are nearly always homozygous for the Ser49 variant, whereas the combination Gly49Gly389 appears not to occur natively (Johnson and Terra 2002). Moreover, codon 49 SNP appears to modulate functional responsiveness of codon 389 SNP: In vitro in HEK293 cells stably transfected with different $\beta-1$ AR haplotypes, isoprenaline evoked maximal cyclic AMP generation with a haplotype order Gly49Arg389>Ser49Arg389>>Ser49Gly389 (Sandilands et al. 2004).

Several studies have investigated possible associations between the $\beta-1$ AR polymorphisms and cardiovascular diseases. Data obtained, however, are rather inconsistent; at present, it seems to be clear that these $\beta-1$ AR polymorphisms are not causally linked to cardiovascular diseases (are not disease-causing genes). They might, however, be involved in modifying progression of diseases and may affect drug responses (Small et al. 2003; Kirstein and Insel 2004; Leineweber et al. 2004; Brodde et al. 2006). Thus, recent data indicate that the Arg389Gly $\beta-1$
AR polymorphism determines cardiac responses to dobutamine: dobutamine-infusion-evoked increases in heart rate and/or contractility were significantly larger in subjects homozygous for the Arg389 $\beta-1$ AR than in subjects with one or two Gly389 alleles (LaRosee et al. 2004; Bruck et al. 2005). Similarly, dobutamine-caused increases in plasma renin activity (an effect mediated by renal $\beta-1$ AR stimulation) were, in Arg389 $\beta-1$ AR subjects, significantly larger than in subjects with one or two Gly389 alleles (Bruck et al. 2005). In addition, preliminary data from our laboratory indicate that patients undergoing $\mathrm{CABG}$, who were homozygous for the Arg389 $\beta-1$ AR, required postCABG for a shorter time a lower dose of catecholamineinduced inotropic support than did patients with one or two Gly389 alleles (Leineweber et al. 2006).

Moreover, during the last few years, evidence has accumulated that heart rate and blood pressure responses to $\beta-1$ AR blocker administration are, in subjects homozygous for the Arg389 $\beta-1 \mathrm{AR}$, more pronounced than in subjects with one or two Gly389 alleles (Fig. 4; for recent review, see Brodde et al. 2006). This holds true not only for studies in healthy volunteers but also in patients with essential hypertension; moreover, several studies have shown that, in CHF patients, chronic $\beta$-AR blocker treatment can improve LVED and survival better in patients homozygous for the Arg389 $\beta$-1 AR polymorphism than in patients carrying one or two Gly389 alleles (Table 2); it should be, however, emphasized that a few studies with negative findings (i.e. no genotype-dependent differences in response to $\beta$-AR blockers) have been also published
Heart Rate

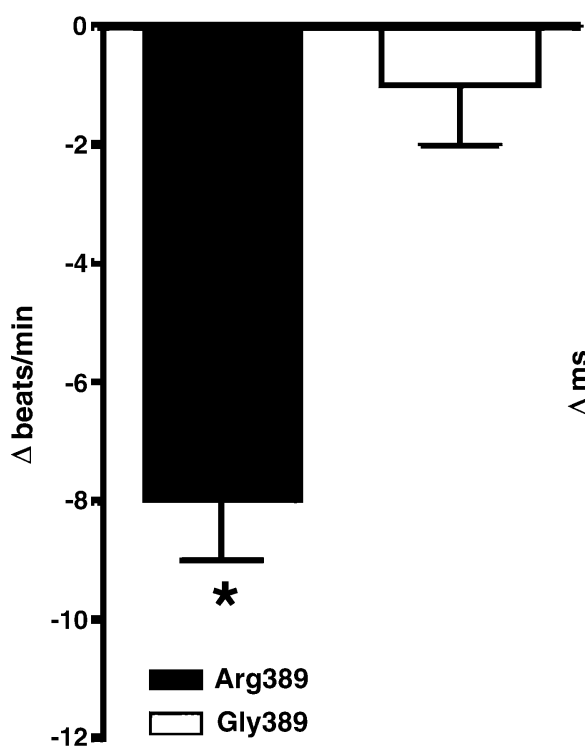

Contractility

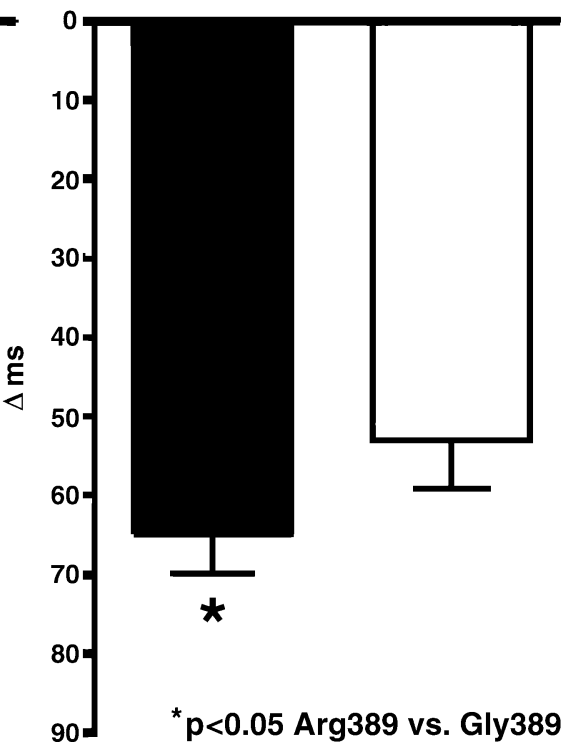

Plasma-Renin-Activity

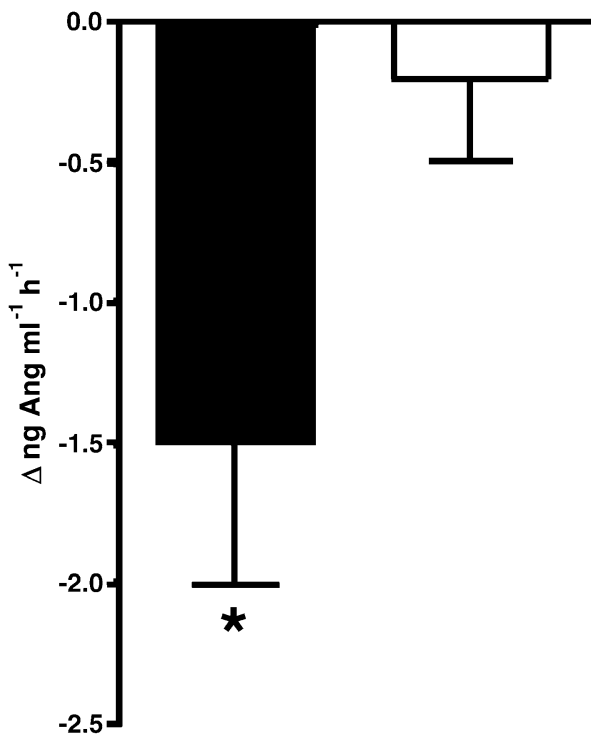

Fig. 4 Bisoprolol (10 mg p.o.)-induced attenuation of dobutamineinfusion induced increases in heart rate, contractility and plasma renin activity in ten male volunteers homozygous for the Arg389 $\beta_{1}$-AR and eight male volunteers homozygous for the Gly389 $\beta_{1}$-AR polymorphism. Ordinates Bisoprolol-induced decrease in dobutamine-evoked increases in heart rate (left, in $\Delta$ beats/min), contractility (middle, in $\Delta \mathrm{ms}$ ) and plasma renin activity (right, in $\Delta \mathrm{ng}$ angiotensin I formed $\mathrm{ml}^{-1} \mathrm{~h}^{-1}$ ). Modified from Bruck et al. (2005) 
Table $2 \beta-1$ AR polymorphisms and response to $\beta$-AR blockers

\begin{tabular}{|c|c|c|c|c|}
\hline$\beta-1 \mathrm{AR}$ & Parameter & Number of cases & $\begin{array}{l}\text { Polymorphism effect } \\
\text { on parameter }\end{array}$ & Reference \\
\hline \multicolumn{5}{|c|}{ Healthy volunteer studies } \\
\hline Arg389Gly & $\begin{array}{l}\text { BPsyst and MAP response to a single dose } \\
\text { of atenolol }\end{array}$ & 44 healthy volunteers & Arg389>Gly389 & Sofowora et al. 2003 \\
\hline Arg389Gly & $\begin{array}{l}\text { Attenuation of exercise-induced HR and } \\
\text { BPsyst increases by metoprolol }\end{array}$ & 16 healthy volunteers & Arg389>Gly389 & Liu et al. 2003 \\
\hline Arg389Gly & $\begin{array}{l}\text { Attenuation of dobutamine-induced HR, } \\
\text { contractility and PRA increases by bisoprolol }\end{array}$ & 18 healthy volunteers & Arg389>Gly389 & Bruck et al. 2005 \\
\hline \multicolumn{5}{|c|}{ Studies with essential hypertensive patients } \\
\hline Arg389Gly & $\begin{array}{l}\mathrm{BP} \text { and } \mathrm{HR} \text { response to chronic } \\
\text { bisoprolol/atenolol treatment }\end{array}$ & $\begin{array}{l}147 \text { patients with } \\
\text { essential hypertension }\end{array}$ & $\operatorname{Arg} 389=$ Gly 389 & $\begin{array}{l}\text { O'Shaughnessy et al. } \\
2000\end{array}$ \\
\hline Arg389Gly & $\begin{array}{l}\text { Daytime BPdiast response to } 4 \text {-week } \\
\text { metoprolol treatment }\end{array}$ & $\begin{array}{l}40 \text { patients with } \\
\text { essential hypertension }\end{array}$ & Arg389>Gly389-carriers & Johnson et al. 2003 \\
\hline Arg389Gly & $\begin{array}{l}\mathrm{BP} \text { and } \mathrm{HR} \text { response to chronic atenolol } \\
\text { treatment }\end{array}$ & $\begin{array}{l}101 \text { patients with } \\
\text { essential hypertension }\end{array}$ & Arg389=Gly389 & Karlsson et al. 2004 \\
\hline Arg389Gly & $\begin{array}{l}\text { BPsyst and BPdiast response to chronic } \\
\text { metoprolol treatment }\end{array}$ & $\begin{array}{l}61 \text { patients with } \\
\text { essential hypertension }\end{array}$ & Arg389>Gly389-carriers & Liu et al. 2006 \\
\hline \multicolumn{5}{|c|}{ Studies with $\mathrm{CHF}$ patients } \\
\hline Arg389Gly & $\begin{array}{l}\text { Chronic metoprolol } \mathrm{CR} / \mathrm{XL} \text { treatment and } \\
\text { HR reduction, survival and adverse effects }\end{array}$ & $\begin{array}{l}600 \text { patients with CHF } \\
\text { (MERIT-HF) }\end{array}$ & Arg389=Gly389 & White et al. 2003 \\
\hline Arg389Gly & $\begin{array}{l}\text { Chronic carvedilol treatment and } \\
\text { improvement of LVEF }\end{array}$ & 224 patients with $\mathrm{CHF}$ & Arg389-carriers $>$ Gly389 & Mialet Perez et al. 2003 \\
\hline Arg389Gly & $\begin{array}{l}\text { Chronic carvedilol or bisoprolol treatment } \\
\text { and improvement of LVEF }\end{array}$ & 199 patients with CHF & $\operatorname{Arg} 389=$ Gly389-carriers & De Groote et al. 2005 \\
\hline Arg389Gly & $\begin{array}{l}\text { Chronic metoprolol CR/XL treatment and } \\
\text { improvement of LVEF }\end{array}$ & 61 patients with $\mathrm{CHF}$ & Arg389>Gly389-carriers & Terra et al. 2005 \\
\hline Arg389Gly & Chronic bucindolol treatment (5-year survival) & 1,040 patients with CHF & Arg389>Gly389-carriers & Liggett et al. 2006 \\
\hline Ser49Gly & Chronic $\beta$-blocker treatment ( 5 -year survival) & 184 patients with $\mathrm{CHF}$ & Gly49-carriers $>$ Ser 49 & Börjesson et al. 2000 \\
\hline Ser49Gly & Chronic $\beta$-blocker treatment ( 5 -year survival) & 375 patients with $\mathrm{CHF}$ & Gly49-carriers $>$ Ser 49 & Magnusson et al. 2005 \\
\hline
\end{tabular}

$H R$ heart rate; BPsyst, BPdiast systolic, diastolic blood pressure; MAP mean arterial blood pressure; $L V E F$ left ventricular ejection fraction; PRA plasma renin activity; $C H F$ chronic heart failure

(Table 2). Nevertheless, it appears to be justified to speculate that it might be possible by assessment of the Arg389Gly $\beta-1$ AR polymorphism to predict responses to $\beta$-AR agonist (and blocker) treatment: Patients homozygous for the Arg389 $\beta$-1 AR polymorphism should be good responders, whereas patients homozygous for the Gly389 $\beta-1$ AR polymorphism should be poor or non-responders.

\section{Conclusion}

There can be no doubt that, in the failing heart, chronic adrenergic signaling is a harmful compensatory mechanism. Noradrenaline, the primary signaling molecule of cardiac adrenergic activity, is a rather $\beta-1$ AR selective agonist (Lands et al. 1967). In several animal studies, and also in humans, it has been shown that chronic activation of cardiac $\beta-1$ AR produces a cardiomyopathic phenotype; similar effects are observed with overexpression of $\beta-1$ AR in the heart of transgenic animals (for references, see Port and Bristow 2001; Lohse et al. 2003; Hata et al. 2004). Moreover, $\beta-1$ AR stimulation can cause ischemia and apoptosis. Thus, it is rather plausible that the principal mechanism of the beneficial effects of $\beta$-AR blockers in treatment of CHF is blockade of this enhanced $\beta-1$ AR signaling, and by this, prevention and partial restoration of adrenergically-induced myocardial dysfunction and remodelling. In addition, $\beta$-AR blocker-induced up-regulation of (previously down-regulated) cardiac $\beta$-AR and normalization of the (previously enhanced) activities of the $\mathrm{G}_{\mathrm{i}}$-protein and GRK may also contribute to the normalization of the $\beta$ AR-G-protein(s)-adenylyl cyclase system, the most powerful physiologic mechanism to acutely augment cardiac performance (Brodde et al. 1995).

Much has been learned in the last two decades on the mechanism underlying these beneficial effects of chronic $\beta$ AR blocker treatment in $\mathrm{CHF}$; however, some open questions still remain:

(1) What is the mechanism underlying up-regulation of $\beta$ AR density by (at least "first and second generation") $\beta$ - 
AR blockers? Originally, it had been assumed that this up-regulation of $\beta$-AR density is due to prevention of the interaction between endogenous agonists (in the case of CHF elevated noradrenaline levels) and the $\beta$-AR. Alternatively, however, it might be the expression of the inverse agonism properties of the $\beta$-AR blockers. The concept of inverse agonism (opposite effects to those of agonists) has evolved from the in vitro observations that certain $\beta$-AR blockers could reduce basal receptor activity present in the absence of agonists ("constitutive receptor activity"). It has been shown in a variety of recombinant systems that long-term treatment with inverse agonists causes much larger increases in receptor density than do "neutral" antagonists (Milligan and Bond 1997). Thus, because the "second generation" $\beta-1$ AR blockers bisoprolol and metoprolol have been shown the exert considerable inverse agonism activity (Maack et al. 2001), it might well be that the increase in $\beta$-AR density observed in human heart during longterm treatment with these $\beta-1$ AR blockers (Brodde et al. 1990; Gilbert et al. 1996; Heilbrunn et al. 1989; Michel et al. 1988; Sigmund et al. 1996; Waagstein et al. 1989) is due to their inverse agonism activity. In this context, it is interesting to note that also carvedilol has been found to exert (weak) inverse agonism (Maack et al. 2000), but as discussed earlier it did not increase cardiac $\beta$-AR density in CHF. As discussed above, the lack of $\beta$-AR-increasing effects of carvedilol might be due to the fact that carvedilol is a "pseudo irreversible antagonist" in the time frame of radioligand-binding studies used to assess $\beta$-AR density, and this might cause technical problems to exactly determine receptor density. In fact, by the use of very high concentrations of the radioligand (ICYP, $\left[{ }^{125} \mathrm{I}\right]$ iodocyanopindolol) to reach true saturation binding, Callaerts-Vegh et al. (2004) recently could demonstrate, in a murine model of asthma, that chronic carvedilol treatment increased $\beta$-AR density in lungs. In this study, the authors observed about 10 - to 15 -fold increase in the $\mathrm{KD}$ value for the radioligand (ICYP), which is compatible with the view that a substantial amount of carvedilol is retained in the lung membranes. Taken together, these data show that also chronic treatment with the "third generation" $\beta$-AR blocker carvedilol can lead to increases in $\beta$-AR density, but again, no such data yet do exist for human heart.

However, it should be emphasized that constitutive activity is only one source of tone in vivo; preexisting receptor activity in humans may also result from varying levels of endogenous agonist, i.e. noradrenaline (that, for example, in CHF is markedly elevated). Thus, in vitro it is possible to examine receptor activity in the absence of other ligands; in vivo, on the other hand, it is rather impossible to study receptors in isolation from their endogenous ligands. Accordingly, inverse agonism of $\beta$-AR blockers may reflect the presence of endogenous agonist (in CHF elevated noradrenaline) rather than constitutive receptor activity, and hence, $\beta$ AR up-regulation by chronic $\beta$-AR blocker treatment may be due to prevention and/or reversal of (endogenous) agonist-induced down-regulation.

(2) Is the decrease in the (in CHF increased) activity of cardiac $\mathrm{G}_{\mathrm{i}}$-protein beneficial or harmful to the failing heart? As discussed earlier, increased $\mathrm{G}_{\mathrm{i}}$-protein activity does not only contribute to attenuation of cardiac $\beta$-AR functional responsiveness but can also prevent adrenergically-evoked apoptosis and arrhythmias. Thus, $\beta$-AR blocker-induced decrease in $\mathrm{G}_{\mathrm{i}}$-protein activity might promote apoptosis, and finally, may, by this, be rather harmful to the failing heart.

(3) Does $\beta$-AR blocker-induced decrease in the (in CHF increased) activity of cardiac GRK2 really contribute to their beneficial effects? In several animal models, it had been shown that inhibition of GRK2 activity caused improvement of cardiac performance. Such an inhibition of GRK2 was achieved by the C-terminal domain of GRK2 (named $\beta$ ARKct) that competes with GRK2 for free $G_{\beta \gamma}$ subunits in the membrane, and thus prevents translocation of (cytosolic) GRK to the membrane (Hata et al. 2004). However, it should be considered that $G_{\beta \gamma}$ proteins exert their own signaling properties including modulation of activity of phospholipase $\mathrm{C}$, potassium channels and other second messenger systems (for recent review, see McCudden et al. 2005). Thus, the beneficial effects of $\beta$ ARKct could be also due to its inhibition of $G_{\beta \gamma}$ signaling. In fact, Li et al. (2003) have recently shown that, in rabbits with rapid ventricular pacing-induced heart failure, phosducin (a known $G_{\beta \gamma}$ subunit-binding protein) exerted very similar beneficial effects on heart failure progression as did $\beta A R K c t$, but phosducin did not restore $\beta-A R$ responsiveness as did $\beta A R K c t$. Thus, it is still an open question whether $\beta$-AR blocker-induced decrease in the (in CHF increased) activity of cardiac GRK2 (Leineweber et al. 2005) can exert beneficial effects in the failing heart without affecting $G_{\beta \gamma}$ signaling.

Taken together, several different mechanisms appear to be involved in the beneficial effects of $\beta$-AR blocker treatment in CHF. However, to decide which of these multiple effects are predominantly responsible for their effects remains to be elucidated by further careful clinical investigations.

Nevertheless, as mentioned several times in this article, the $\beta$-AR-G-protein(s)-adenylyl cyclase system is the most 
powerful physiological mechanism to augment human cardiac performance. It should be considered, therefore, that chronic desensitization of this system in CHF over a long time period can not only be a "protective mechanism" (to prevent all detrimental effects of chronic cardiac $\beta$-AR overstimulation) but it also must impair and weaken cardiac performance, and this might be rather harmful for the human heart. Thus, it is quite likely that the most important mechanism underlying the beneficial effects of chronic $\beta$ AR treatment in CHF is the resensitization of this system on all levels (up-regulation of previously down-regulated $\beta$-AR, reductions of previously elevated $G_{i}$-protein and GRK), whereby this occurs in a balanced manner: The $\beta$ AR-G-protein(s)-adenylyl cyclase system is normalized to be able to provide improved cardiac performance, but overstimulation-induced detrimental effects of the system will be prevented by the simultaneous blocking activity of the $\beta$-AR blockers.

Acknowledgement Part of the author's work cited in this article was supported by grants of the Deutsche Forschungsgemeinschaft (Bonn/ Germany: DFG BR 526/8-1, BR526/8-3, BR526/10-1), the Deutsche Herzstiftung und the Nationales Genomforschungsnetz (Förderzeichen 01GS0107).

\section{References}

Aarons RD, Molinoff PB (1982) Changes in density of beta adrenergic receptors in rat lymphocytes, heart and lung after chronic treatment with propranolol. J Pharmacol Exp Ther 221:439-443

Ahlquist RP (1948) A study of the adrenotropic receptors. Am J Physiol 153:586-600

Andreka P, Aiyar N, Olson LC, Wei JQ, Turner MS, Webster KA, Ohlstein EH, Bishopric NH (2002) Bucindolol displays intrinsic sympathomimetic activity in human myocardium. Circulation 105:2429-2434

Bhargava V, Shabetai R, Mathiäsen RA, Dalton N, Hunter JJ, Ross J $\mathrm{Jr}$ (1998) Loss of adrenergic control of the force-frequency relation in heart failure secondary to idiopathic or ischemic cardiomyopathy. Am J Cardiol 81:1130-1137

Black JW, Crowther AF, Shanks RG, Smith LH, Dornhorst AC (1964) A new adrenergic beta-receptor antagonist. Lancet 1:1080-1081

Böhm M, LaRosee K, Schwinger RHG, Erdmann E (1995) Evidence for reduction of noradrenaline uptake sites in the failing human heart. J Am Coll Cardiol 25:146-153

Börjesson M, Magnusson Y, Hjalmarson A, Andersson B (2000) A novel polymorphism in the gene coding for the beta ${ }_{1}$-adrenergic receptor associated with survival in patients with heart failure. Eur Heart J 21:1853-1858

Bowditch HP (1871) Über die Eigentümlichkeiten der Reizbarkeit welche die Muskelfasern des Herzens zeigen. Arb Physiol Anst Leipz 6:139-176

Brattelid T, Qvigstad E, Lynham JA, Molenaar P, Aass H, Geiran O, Skomedal T, Osnes J-B, Levy FO, Kaumann AJ (2004) Functional serotonin $5-\mathrm{HT}_{4}$ receptors in porcine and human ventricular myocardium with increased $5-\mathrm{HT}_{4}$ mRNA in heart failure. Naunyn-Schmiedeberg's Arch Pharmacol 370:157-166

Bristow MR (2000) $\beta$-Adrenergic receptor blockade in chronic heart failure. Circulation 101:558-569
Bristow MR, Ginsburg R, Minobe W, Cubicciotti RS, Sageman WS, Lurie K, Billingham ME, Harrison DC, Stinson EB (1982) Decreased catecholamine sensitivity and $\beta$-adrenergicreceptor density in failing human hearts. $\mathrm{N}$ Engl $\mathrm{J}$ Med 307:205-211

Brodde O-E (1993) Beta-adrenoceptors in cardiac disease. Pharmacol Ther 60:405-430

Brodde O-E, Leineweber K (2004) Autonomic receptor systems in the failing and aging human heart: similarities and differences. Eur J Pharmacol 500:167-176

Brodde O-E, Michel MC (1999) Adrenergic and muscarinic receptors in the human heart. Pharmacol Rev 51:651-689

Brodde O-E, Wang XL (1988) Beta adrenoceptor changes in blood lymphocytes and altered drug responsiveness. Ann Clin Res 20:311-323

Brodde O-E, Daul A, Stuka N, O'Hara N, Borchard U (1985) Effects of $\beta$-adrenoceptor antagonist administration on $\beta_{2}$-adrenoceptor density in human lymphocytes. The role of the "intrinsic sympathomimetic activity". Naunyn-Schmiedeberg's Arch Pharmacol 328:417-422

Brodde O-E, Zerkowski H-R, Doetsch N, Khamssi M (1989) Subtype-selective up-regulation of human saphenous vein $\beta_{2^{-}}$ adrenoceptors by chronic $\beta$-adrenoceptor antagonist treatment. Naunyn-Schmiedeberg's Arch Pharmacol 339:479-482

Brodde O-E, Daul A, Michel MC (1990) Subtype-selective modulation of human $\beta_{1}$ - and $\beta_{2}$-adrenoceptor function by $\beta$-adrenoceptor agonists and antagonists. Clin Physiol Biochem 8(Suppl 2): $11-17$

Brodde O-E, Michel MC, Zerkowski H-R (1995) Signal transduction mechanisms controlling cardiac contractility and their alterations in chronic heart failure. Cardiovasc Res 30:570-584

Brodde O-E, Bruck H, Leineweber K (2006) Cardiac adrenoceptors: physiological and pathophysiological relevance. J Pharmacol Sci 100:323-337

Bruck H, Leineweber K, Temme T, Weber M, Heusch G, Philipp T,

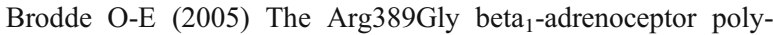
morphism and catecholamine effects on plasma-renin activity. $\mathrm{J}$ Am Coll Cardiol 46:2111-2115

Bylund DB, Eikenberg DC, Hieble PJ et al (1994) International union of pharmacology: nomenclature of adrenoceptors. Pharmacol Rev 46:121-136

Callaerts-Vegh Z, Evans KLJ, Dudekula N, Cuba D, Knoll BJ, Callaerts PFK, Giles H, Shardonofsky FR, Bond RA (2004) Effects of acute and chronic administration of $\beta$-adrenoceptor ligands on airway function in a murine model of asthma. Proc Natl Acad Sci USA 101:4948-4953

Chidsey CA, Braunwald E (1966) Sympathetic activity and neurotransmitter depletion in congestive heart failure. Pharmacol Rev $18: 685-700$

Cohn JN (1990) Abnormalities of peripheral sympathetic nervous system control in congestive heart failure. Circulation 82(Suppl I): I-59-I-67

Cohn JN, Levine TB, Olivari M, Garberg V, Lura D, Francis GS, Simon AB, Rector T (1984) Plasma norepinephrine as a guide to prognosis in patients with chronic congestive heart failure. $\mathrm{N}$ Engl J Med 305:185-190

Communal C, Singh K, Sawyer DB, Colucci WS (1999) Opposing effects of beta(1)- and beta(2)-adrenergic receptors on cardiac myocyte apoptosis: role of a pertussis toxin-sensitive G-protein. Circulation 100:2210-2212

De Groote P, Helbecque N, Lamblin N, Hermant X, McFadden E, Foucher-Hossein C, Amouyel P, Dallongeville J, Bauters C (2005) Association between beta- 1 and beta- 2 adrenergic receptor gene polymorphisms and the response to beta-blockade in patients with stable congestive heart failure. Pharmacogenet Genomics 15:137-142 
Eisenhofer G, Friberg P, Rundqvist B, Quyyumi AA, Lambert G, Kaye DM, Kopin IJ, Goldstein DS, Esler MD (1996) Cardiac sympathetic nerve function in congestive heart failure. Circulation 93:1667-1676

El-Armouche A, Zolk O, Rau T, Eschenhagen T (2003) Inhibitory Gproteins and their role in desensitization of the adenylyl cyclase pathway in heart failure. Cardiovasc Res 60:478-487

Eschenhagen T, Mende U, Diederich M, Hertle B, Memmesheimer C, Pohl A, Schmitz W, Scholz H, Steinfath M, Böhm M, Michel MC, Brodde O-E, Raap A (1996) Chronic treatment with carbachol sensitizes the myocardium to cAMP-induced arrhythmia. Circulation 93:763-771

Esler M, Kaye D, Lambert G, Esler D, Jennings G (1997) Adrenergic nervous system in heart failure. Am J Cardiol 80:7L-14L

Gilbert EM, Abraham WT, Olsen S, Hattler B, White M, Mealy P, Larrabee P, Bristow MR (1996) Comparative hemodynamic, left ventricular functional, and antiadrenergic effects of chronic treatment with metoprolol versus carvedilol in the failing heart. Circulation 94:2817-2825

Gottlieb SS, McCarter RJ, Vogel RA (1998) Effect of beta-blockade on mortality among high-risk and low-risk patients after myocardial infarction. N Engl J Med 339:489-497

Grimm M, Gsell S, Mittmann C, Nose M, Scholz H, Weil J, Eschenhagen $\mathrm{T}$ (1998) Inactivation of $G_{i \alpha}$ proteins increases arrhythmogenic effects of $\beta$-adrenergic stimulation in the heart. $\mathrm{J}$ Mol Cell Cardiol 30:1917-1928

Hall JA, Kaumann AJ, Brown MJ (1990) Selective $\beta_{1}$-adrenoceptor blockade enhances positive inotropic responses to endogenous catecholamines mediated through $\beta_{2}$-adrenoceptors in human atrial myocardium. Circ Res 66:1610-1623

Hall JA, Petch MC, Brown MJ (1991) In vivo demonstration of cardiac $\beta_{2}$-adrenoreceptor sensitization by $\beta_{1}$-antagonist treatment. Circ Res 69:959-964

Hata JA, Williams ML, Koch WJ (2004) Genetic manipulation of myocardial $\beta$-adrenergic receptor activation and desensitization. J Mol Cell Cardiol 37:11-21

Heilbrunn SM, Shah P, Bristow MR, Valantine HA, Ginsburg R, Fowler MB (1989) Increased $\beta$-receptor density and improved hemodynamic response to catecholamine stimulation during long-term metoprolol therapy in heart failure from dilated cardiomyopathy. Circulation 79:483-490

Iaccarino G, Tomhave ED, Lefkowitz RJ, Koch WJ (1998) Reciprocal in vivo regulation of myocardial $G$ protein-coupled receptor kinase expression by $\beta$-adrenergic receptor stimulation and blockade. Circulation 98:1783-1789

Johnson JA, Terra SG (2002) $\beta$-Adrenergic receptor polymorphisms: cardiovascular disease associations and pharmacogenetics. Pharm Res 19:1779-1787

Johnson JA, Zineh I, Puckett BJ, McGorray SP, Yarandi HN, Pauly DF (2003) $\beta_{1}$-Adrenergic receptor polymorphisms and antihypertensive response to metoprolol. Clin Pharmacol Ther 74:4452

Just H (1996) Pathophysiological targets for beta-blocker therapy in congestive heart failure. Eur Heart J 17(Suppl B):2-7

Karlsson J, Lind L, Hallberg P, Michaelsson K, Kurland L, Kahan T, Malmqvist K, Öhman KP, Nyström F, Melhus H (2004) Beta $_{1}$-adrenergic receptor gene polymorphisms and response to beta $_{1}$-adrenergic receptor blockade in patients with essential hypertension. Clin Cardiol 27:347-350

Kindermann M, Maack C, Schaller S, Finkler N, Schmidt KI, Laer S, Wuttke H, Schäfers H-J, Böhm M (2004) Carvedilol but not metoprolol reduced $\beta$-adrenergic responsiveness after complete elimination from plasma in vivo. Circulation 109:3182-3190

Kirstein SL, Insel PA (2004) Autonomic nervous system pharmacogenomics: a progress report. Pharmacol Rev 56:31-52
Lands AM, Arnold A, McAuliff JP, Luduena FP, Brown TG (1967) Differentiation of receptor systems activated by sympathomimetic amines. Nature 214:597-598

Langer SZ (1974) Presynaptic regulation of catecholamine release. Biochem Pharmacol 23:1793-1800

LaRosee K, Huntgeburth M, Rosenkranz S, Böhm M, Schnabel P (2004) The Arg389Gly $\beta_{1}$-adrenoceptor gene polymorphism determines contractile response to catecholamines. Pharmacogenetics 14:711716

Leineweber K, Klapproth S, Beilfuss A, Silber RE, Heusch G, Philipp T, Brodde O-E (2003) Unchanged G-protein-coupled receptor kinase activity in the aging human heart. J Am Coll Cardiol 42:1487-1492

Leineweber K, Büscher R, Bruck H, Brodde O-E (2004) $\beta$ Adrenoceptor polymorphisms. Naunyn-Schmiedeberg's Arch Pharmacol 369:1-22

Leineweber K, Rohe P, Beilfuß A, Wolf C, Sporkmann H, Bruck H, Jakob H-G, Heusch G, Philipp T, Brodde O-E (2005) G-Proteincoupled receptor kinase activity in human heart failure: effects of $\beta$-adrenoceptor blockade. Cardiovasc Res 66:512-519

Leineweber K, Bruck H, Brodde O-E (2006) Inotropic catecholamine support after coronary artery bypass surgery in relation to Arg389Gly $\beta_{1}$-adrenoceptor polymorphism. Br J Clin Pharmacol 61:612 (abstr)

Li Z, Laugwitz K-L, Pinkernell K, Pragst I, Baumgartner C, Hoffmann E, Rosport K, Münch C, Moretti A, Humrich J, Lohse MJ, Ungerer M (2003) Effects of two $G_{\beta \gamma}$-binding proteins- $\mathrm{N}$-terminally truncated phosducin and $\beta$-adrenergic receptor kinase $\mathrm{C}$ terminus ( $\beta \mathrm{ARKct}$ )-in heart failure. Gene Ther 10:1354-1361

Liggett SB, Mialet-Perez J, Thaneemit-Chen S, Weber SA, Greene SM, Hodne D, Nelson B, Morrison J, Domanski MJ, Wagoner LE, Abraham WT, Anderson JL, Carlquist JF, Krause-Steinrauf HJ, Lazzeroni LC, Port JD, Lavori PW, Bristow MR (2006) A polymorphism within a conserved $\beta_{1}$-adrenergic receptor motif alters cardiac function and $\beta$-blocker response in human heart failure. Proc Natl Acad Sci USA 103:11288-11293

Liu J, Liu Z-Q, Tan Z-R, Chen X-P, Wang L-S, Zhou G, Zhou H-H (2003) Gly389Arg polymorphism of $\beta_{1}$-adrenergic receptor is associated with the cardiovascular response to metoprolol. Clin Pharmacol Ther 74:372-379

Liu J, Liu Z-Q, Yu B-N, Xu F-H, Mo W, Zhou G, Liu Y-Z, Li Q, Zhou $\mathrm{H}-\mathrm{H}$ (2006) $\beta_{1}$-Adrenergic receptor polymorphisms influence the response to metoprolol monotherapy in patients with essential hypertension. Clin Pharmacol Ther 80:23-32

Lohse MJ, Engelhardt S, Eschenhagen T (2003) What is the role of the $\beta$-adrenergic signaling in heart failure? Circ Res 93:896-906

Maack C, Cremers B, Flesch M, Höper A, Südkamp M, Böhm M (2000) Different intrinsic activities of bucindolol, carvedilol and metoprolol in human failing myocardium. $\mathrm{Br} \mathrm{J}$ Pharmacol 130:1131-1139

Maack C, Tyroller S, Schnabel P, Cremers B, Dabew E, Südkamp M, Böhm M (2001) Characterization of $\beta_{1}$-selectivity, adrenoceptor$\mathrm{G}_{\mathrm{s}}$-protein interaction and inverse agonism of nebivolol in human myocardium. Br J Pharmacol 132:1817-1826

Maack C, Böhm M, Vlaskin L, Dabew E, Lorenz K, Schäfers H-J, Lohse MJ, Engelhardt S (2003) Partial agonist activity of bucindolol is dependent on the activation of the human $\beta_{1}$ adrenergic receptor. Circulation 108:348-353

Magnusson Y, Levin MC, Eggertsen R, Nyström E, Mobini R, Schaufelberger M, Andersson B (2005) Ser49Gly of $\beta_{1}$-adrenergic receptor is associated with effective $\beta$-blocker dose in dilated cardiomyopathy. Clin Pharmacol Ther 78:221-231

McCudden CR, Hains MD, Kimple RJ, Siderovski DP, Willard FS (2005) G-protein signaling: back to the future. Cell Mol Life Sci 62:551-557 
Mialet Perez J, Rathz DA, Petrashevskaya NN, Hahn HS, Wagoner LE, Schwartz A, Dorn II GW, Liggett SB (2003) $\beta_{1}$-Adrenergic receptor polymorphisms confer differential function and predisposition to heart failure. Nature Med 9:1300-1305

Michel MC, Pingsmann A, Beckeringh JJ, Zerkowski H-R, Doetsch $N$, Brodde O-E (1988) Selective regulation of $\beta_{1^{-}}$and $\beta_{2^{-}}$ adrenoceptors in the human heart by chronic $\beta$-adrenoceptor antagonist treatment. Br J Pharmacol 94:685-692

Milligan G, Bond RA (1997) Inverse agonism and the regulation of receptor number. Trends Pharmacol Sci 18:468-474

Motomura S, Deighton NM, Zerkowski H-R, Doetsch N, Michel MC, Brodde O-E (1990) Chronic $\beta_{1}$-adrenoceptor antagonist treatment sensitizes $\beta_{2}$-adrenoceptors, but desensitizes $\mathrm{M}_{2}$-muscarinic receptors in the human right atrium. Br J Pharmacol 101:363-369

O'Shaughnessy KM, Fu B, Dickerson C, Thurston D, Brown MJ (2000) The gain-of-function G389R variant of the $\beta_{1}$-adrenoceptor does not influence blood pressure or heart rate response to $\beta$-blockade in hypertensive subjects. Clin Sci 99:233-238

Penela P, Ribas C, Mayor F (2003) Mechanisms of regulation of the expression and function of $\mathrm{G}$ protein-coupled receptor kinases. Cell Signal 15:973-981

Penela P, Murga C, Ribas C, Tutor AS, Peregrin S, Mayor F Jr (2006) Mechanism of regulation of $G$ protein-coupled receptor kinases (GRKs) and cardiovascular disease. Cardiovasc Res 69:46-56

Penn RB, Pronin AN, Benovic JL (2000) Regulation of G proteincoupled receptor kinases. Trends Cardiovasc Med 10:81-89

Ping P, Gelzer-Bell R, Roth DA, Kiel D, Insel PA, Hammond HK (1995) Reduced $\beta$-adrenergic receptor activation decreases $G$ protein expression and $\beta$-adrenergic receptor kinase activity in porcine heart. J Clin Invest 95:1271-1280

Port JD, Bristow MR (2001) Altered beta-adrenergic receptor gene regulation and signaling in chronic heart failure. $\mathrm{J}$ Mol Cell Cardiol 33:887-905

Sandilands A, Yeo G, Brown MJ, O'Shaughnessy KM (2004) Functional responses of human $\beta 1$ adrenoceptors with defined haplotypes for the common $389 \mathrm{R}>\mathrm{G}$ and $49 \mathrm{~S}>\mathrm{G}$ polymorphisms. Pharmacogenetics 14:343-349
Sigmund M, Jakob H, Becker H, Hanrath P, Schumacher C, Eschenhagen T, Schmitz W, Scholz H, Steinfath M (1996) Effects of metoprolol on myocardial $\beta$-adrenoceptors and $G_{i \alpha}$ proteins in patients with congestive heart failure. Eur J Clin Pharmacol 51:127-132

Small KM, McGraw DW, Liggett SB (2003) Pharmacology and physiology of human adrenergic receptor polymorphisms. Annu Rev Pharmacol Toxicol 43:381-411

Sofowora GG, Dishy V, Muszkat M, Xie HG, Kim RB, Harris PA, Prasad HC, Byrne DW, Nair UB, Wood AJJ, Stein CM (2003) A common $\beta_{1}$-adrenergic receptor polymorphism (Arg389Gly) affects blood pressure response to $\beta$-blockade. Clin Pharmacol Ther 73:366-371

Starke K (1977) Regulation of noradrenaline release by presynaptic receptor systems. Rev Physiol Biochem Pharmacol 77:1-124

Terra SG, Hamilton KK, Pauly DF, Lee CR, Patterson JH, Adams KF, Schofield RS, Belgado BS, Hill JA, Aranda JM, Yarandi HN, Johnson JA (2005) $\beta_{1}$-Adenergic receptor polymorphisms and left ventricular remodeling changes in response to $\beta$-blocker therapy. Pharmacogenet Genomics 15:227-234

Ungerer M, Böhm M, Elce JS, Erdmann E, Lohse MJ (1993) Altered expression of $\beta$-adrenergic receptor kinase and $\beta_{1}$ adrenergic receptors in the failing human heart. Circulation $87: 454-463$

Waagstein F, Caidahl K, Wallentin I, Bergh C-H, Hjalmarson A (1989) Long-term $\beta$-blockade in dilated cardiomyopathy. Effects of shortand long-term metoprolol treatment followed by withdrawal and readministration of metoprolol. Circulation 80:551-563

White HL, De Boer RA, Maqbool A, Greenwood D, Van Veldhuisen DJ, Cuthbert R, Ball SG, Hall AS, Balmforth AJ, on behalf of the MERIT-HF study group (2003) An evaluation of the beta-1 adrenergic receptor Arg389Gly polymorphism in individuals with heart failure: a MERIT-HF sub-study. Eur J Heart Fail 5:463-468

Xiao R-P, Zhu W, Zheng M, Chakir K, Bond RA, Lakatta EG, Cheng $H$ (2004) Subtype-specific $\beta$-adrenoceptor signaling pathways in the heart and their potential clinical implications. Trends Pharmacol Sci 25:358-365 